\title{
KLASIFIKASI INSTRUMEN MUSIK PADA ENSEMBEL MUSIK TRADISIONAL BATAK TOBA
}

\author{
Roy J M Hutagalung \\ Institut Agama Kristen Negeri Tarutung \\ E-mail: hutagalungjuan0@gmail.com
}

\begin{abstract}
Abstrak-Artikel ini bertujuan untuk mengklasifikasi instrumen musik, pada ensembel musik tradisional Batak Toba. Artikel ini merupakan kajian pustaka yang menganalisis berbagai teori ahli tentang klasifikasi instrumen musik pada ensembel musik tradisional Batak Toba. Hasil kajian ini menunjukkan bahwa klasifikasi instrumen Batak Toba di klasifikasikan untuk ansambel gondang sabangunan, taganing (membranophone), gordang (membranophone), odap (membranophone), ogung oloan (idiophone), sarune (aerophone), ogung ihutan (idiophone), doal (idiophone), panggora (idiophone), hesek (idiophone) untuk ansambel gondang hasapi, hasapi ende (chordophone), hasapi doal (chordophone), sarune etek (aerophone), sulim (aerophone), garantung (idiophone, hesek (idiophone). Stratifikasi pargonsi khususnya instrumen taganing(membranophone) yang disebut partaganing mendapat posisi khusus karena dianggap sebagai seorang yang memiliki kemampuan sebagai penghubung antara manusia dengan sang pencipta. Kedudukan seorang pargonsi dalam stratifikasi sosial masyarakat yang tidak permanen. Di satu sisi dianggap sebagai wakil dewa, yaitu ketika memainkan ansambel gondang pada saat upacara, di sisi lain sebagai masyarakat biasa yang terikat dengan sistem kemasyarakatan dan kekerabatan yang terdapat dalam dalihan na tolu tetika tidak berperan sebagai pargonsi. Status mereka adalah sama dengan individu lainnya berdasarkan pekerjaan sehari-hari, misalnya sebagai petani, nelayan, pedagang dan sebagainya. Prinsip klasifikasi berdasarkan uraian yang dikemukakan oleh Mahillon-Sachs-VonHornbostel dalam kaitannya dengan pengelompokan alat musik yang dilakukan secara lokal pada alat-alat musik tradisional Batak Toba, pada prinsipnya mengacu pada teori klasifikasi oleh Mahillon-SachsVonHornbostelnamun di sisi lain secara spesifik pengelompokan yang dilakukan secara local, berdasar pada fungsi alat musik dalam sebuah ansambel baik pada gondang sabangunan maupun gondang hasapi.
\end{abstract}

Kata kunci: klasifikasi, instrumen musik, ensembel, musik tradisional, batak toba

\section{PENDAHULUAN}

Bidang yang menempatkan musik
tradisional sebagai objek sentral
pembahasannya menjadi sebuah cabang ilmu
yang khusus pula, yang disebut dengan
Etnomusikologi yang memberi perhatian yang
khusus pada perkembangan musik tradisional.
Dengan dasar pengetahuan etnomusikologi itu
masing-masing negara menemukan
metodenya sendiri yang cocok dan kita harus
melakukan itu.

Etnomusikologi merupakan bagian dari musikologi, etnomusikologi terpisah dari musikologi pada abad XIX. Pada Awalnya ilmu itu tidak disebut etnomusikologi, tetapi "verglechende Musikwissenschaft" atau musik perbandingan seperti yang dicanangkan oleh Erich von Hornbostel, disebut demikian karena peneliti pada masa itu benar-benar membandingkan musik-musik yang ada di dunia ini. Tentu terjadi perbedaan pendapat diantara para peneliti, salah satu diantaranya 
misalnya Alexander Jhon Ellis yang meneliti akustik musik etnis tanpa menghiraukan kebudayaanya atau latar belakang musik tersebut.

Menurut penulis etnomusikologi adalah membuat etnografi akustik atau etnografi musik (suara) yang mana hal ini sebagai pembeda dengan antropologi, hal ini berarti peneliti mendekati musik dengan cara berbeda yaitu dengan cara pendekatan musikologi yang menekankan penelitiannya pada musik Barat, misalnya penelitian di bidang sejarah musik Barat, estetika musik Barat dan lain sebagainya.

Penulis menyimpulkan Ilmu etnomusikolgi pada mulanya berupa kegiatan meneliti nada-nada dan alat-alat musik bangsa lain, kemudian berkembang menjadi mencari hubungan antara musik dengan manusia dalam kebudayaannya dengan menggunakan hasil penelitian antropologi selama kurang lebih seratus tahun ini, dan proses ini disebut dengan perubahan perspektif, yaitu perubahan dari etnosentrisme menjadi etnorelativisme.

Dalam konteks Batak Toba, musik tradisionalnya berkembang di kawasan geokultural, memiliki kekayaan yang beragam dari segi warna musik, skala nada, alat-alat musik (instrument musik), ensembel, teknik produksi suara dan pengaruh-pengaruh dari budaya-budaya lainnya.

Alat-alat musik (instrument musik) berperan sebagai media yaitu alat pengantar atau penyalur ide-ide komponis dalam suatu komposisi yang ditulis dalam bentuk partitur (tulisan musik). Dalam hal ini pemain musik melalui alat musiknya mewujudkan partitur dalam bentuk nada-nada yang aktual. Dengan kata lain si pemain menerjermahkan simbolsimbol nada atau not yang tertulis, ke ujud nada fisikal melalui medium berupa satu atau beberapa instrumen. Pada musik vokal, si penyanyi sekaligus berperan sebagai pemain dan medium.

Instrumen musik telah ada sejak manusia mengenal peradaban, dimana setiap suku bangsa (etnik) di seluruh penjuru dunia masing-masing memiliki musik etnik yang peran dan fungsinya berkaitan dengan siklus kehidupan masyarakatnya. Musik berperan sebagai medium dalam berbagai upacara ritual baik yang bersifat magis, adat-istiadat maupun hiburan. Alat-alat musik sepanjang perjalanan sejarah kebudayaan senantiasa berkembang kendati dengan dinamika yang sangat lambat (evolusi) dari bentuk yang paling sederhana hingga pada bentuk baku seperti sekarang ini, yang sangat beragam baik bentuk, bahan, cara memainkan, karakter suara, dan berbagai spesifikasi lainnya.

Klasifikasi instrumen musik dilakukan untuk menentukan dan mengelompokkan konsep-konsep yang memungkinkan penyusunan spektrum dari berbagai alat musik pada tingkat yang lebih bermakna. Selain untuk kepentingan permuseuman pengelompokan alat-alat musik sangat penting dalam studi orkestrasi.

$$
\text { Dengan mengaplikasikan berbagai }
$$
bidang studi musik, dapat ditentukan hubungan antara kualitas, akustika, aspekaspek konstruksi terhadap teknik memainkan suatu instrumen. Dalam hal klasifikasi instrumen di antara para ahli musik terdapat beberapa perbedaan pendapat. Perbedaan pendapat tersebut merupakan sesuatu yang lazim, karena setiap ahli dalam melakukan klasifikasi instrumen cenderung didominasi oleh kepentingan masing-masing. Juga dikarenakan adanya kecenderungan dalam penelitian alat-alat musik lebih berorientasi kepada perluasan pandangan dalam konteks prespektif permuseuman, yaitu konsentrasi kepada objek yang dapat dipajangkan dalam pameran, dengan maksud untuk memperlihatkan alat-alat musik sebagai objek yang dipakai dalam penelitian tersebut.

Muncul pertanyaan tentang bagaimana pendekatan prinsip atau konsepsi pengelompokan alat-alat musik tradisional yang digunakan dalam ansambel musik tradisional Batak Toba? Ada dua pendekatan 
prinsip atau konsepsi yang penulis kombinasikan, pertama stratifikasi pargonsi dan kedua adalah klasifikasi instrumen, pendekatan kedua prinsip atau konsepsi ini dilakukan agar tidak tampak seperti konteks prespektif permuseuman, dalam hal ini penulis memaparkan stratifikasi pargonsi untuk melihat kedudukannya dalam konteks alat-alat musik tradisional (musik etnik).

Konteks perspektif permuseuman memiliki perbedaan dengan kedua pendekatan prinsip atau konsepsi klasifikasi alat-alat musik sebagaimana dikemukakan di atas, karena berkaitan dengan fungsi musik dalam konteks sistem religi atau adat istiadat. Kemudian dalam hal konsepsi klasifikasi, pendekatan konsepsi klasifikasi instrumen Batak Toba perlu dijelaskan dengan sistem klasifikasi alat musik yang dirancang oleh Viktor Charles Mahilon pada abad ke-19, Mahilon membagi alat musik kedalam empat kategori kasar berdasarkan sifat material penghasil suara yaitu kolom udara, senar, membran dan tubuh instrumen, Kemudian atas dasar ide tersebut Hornbostel dan Sach mengembangkan sistem Mahilon untuk memungkinkan klasifikasi setiap alat musik dari setiap kebudayaan, maka hasilnya adalah sistem klasifikasi Hornbostel-Sach atau SachHornbostel, sistem ini pertama kali dipublikasikan di Zeitschrift fur Ethnologie pada tahun 1914.

\section{METODE}

Penelitian ini menggunakan pendekatan penelitian kualitatif deskriptif dikarenakan variabel penelitian merupakan objek yang tidak perlu menggunakan pengukuran dan proses statistik. Menurut Moleong (2001: 6), data penelitian kualitatif yang dikumpulkan adalah data yang berupa kata-kata, gambar, dan bukan merupakan angka-angka.

Penelitian ini bertujuan untuk mengklasifikasi instrumen musik, pada ensembel musik tradisional Batak Toba. Artikel ini merupakan kajian pustaka yang menganalisis berbagai teori ahli tentang klasifikasi instrumen musik pada ensembel musik tradisional Batak Toba.

\section{PEMBAHASAN \\ 3.1.Stratifikasi Pargonsi}

Batak Toba, merupakan salah satu suku bangsa (etnik) yang bermukim dan berasal dari Tapanuli bahagian Utara, Provinsi Sumatera Utara, Indonesia. Sumatera Utara adalah salah satu provinsi di Indonesia, yang penduduknya terdiri dari berbagai kelompok etnik, yang dapat dikategorikan ke dalam tiga kelompok. Kelompok pertama ialah etnik setempat, yang terdiri dari delapan kelompok etnik, yaitu: Melayu, Karo, Pakpak-Dairi, Batak Toba, Simalungun, MandailingAngkola, Pesisir Tapanuli Tengah, dan Nias, ditambah etnik Lubu dan Siladang (Muhammad Takari 2008 : 67).

Secara geografis-kultural, masyarakat Batak Toba terbagi dalam empat wilayah yaitu, (1) Silindung, meliputi daerah Sipoholon, Tarutung, Huta Barat, Pahae, Pansur Batu, dan Adian Koting. (2) Humbang meliputi daerah dataran tinggi Siborongborong, Sipahutar, Pangaribuan, Dolok Sanggul, dan Tele. (3) Samosir meliputi daerah yang ada di Pulau Samosir yaitu, Tomok, Ambarita, Harian Boho, Simanindo, Pangururan, dan Nainggolan. (4) Toba meliputi daerah-daerah di tepian danau Toba seperti Lumban Julu, Porsea, Balige, Muara, dan Bakkara, Ke-empat wilayah ini di kalangan masyarakat Batak Toba disebut sebagai bonapasogit (kampung asal atau kampung halaman). Dari bonapasogit inilah komunitas Batak Toba berimigrasi ke berbagai daerah di Indonesia. Banyak hal yang mendasari atau mempengaruhi migrasi tersebut yakni untuk melanjutkan sekolah, berdagang, bekerja di luar sektor pertanian atau sengaja merantau untuk mencari lahan pertanian baru (manombang).

Dari perspektif kognitif, musik adalah produk konvensi budaya dan fakta 
perwujudannya secara seketika dalam kognisi anggota budaya tersebut (Djohan 2003:7).Tidak satupun masyarakat atau budaya yang tidak memiliki musik, atau setiap orang memerlukan musik dan setiap anggota masyarakatnya adalah musikal (Blacking $\mathbf{J}$ 1995:35). Musik adalah perilaku sosial yang kompleks dan universal. Setiap masyarakat memiliki apa yang disebut dengan musik.

Tradisi adalah suatu struktur kreativitas yang sudah establish (Joiner dalam Coplan 1993:40), yang memberikan gambaran mentalitas, prinsip-prinsip ekspresif, dan nilainilai estetik. Tradisi, walaupun merepresentasikan kekinian tetapi tidak terpisahkan dengan masa lalu (Beisele dalam Coplan 1993:40).

Kendati etnik Batak Toba telah berbaur dengan suku-suku lainnya di perantauan, namun tradisi adat-istiadat yang berlaku di bonapasogit selalu dilaksanakan dan dijunjung tinggi. Hal ini dapat terlihat dalam berbagai aktivitas pelaksanaan berbagai pesta adat seperti upacara perkawinan, upacara kematian, dan berbagai kegiatan lainnya, tidak terlepas dari tradisi yang ada di bonapasogit. Adat diekspresikan lewat berbagai kegiatan adat secara individu maupun secara kolektif (Mauly P 2007: 3).

Dinamika kehidupan etnik Batak Toba mulai dari siklus masa awal perkawinan, kehamilan, kelahiran, pertumbuhan hingga dewasa, kemudian kawin, tua, dan kematian selalu diatur dan mengacu pada adat atau tradisi yang diwarisi secara turun temurun dari nenek moyang hingga kini.

Sistem kekerabatan dalam komunitas Batak Toba adalah patrilineal yaitu menurut garis keturunan ayah. Oleh karena itu masyarakat ini menyebut anggota marganya sebagai dongan sabutuha (mereka yang berasal dari rahim yang sama). Garis keturunan seorang lelaki diteruskan oleh anak lelaki, dan menjadi punah kalau tidak mempunyai anak laki-laki. Sistem kekerabatan patilineal itulah yang menjadi tulang punggung masyarakat Batak Toba, yang terdiri dari turunan-turunan, marga dan kelompok-kelompok suku, semuanya saling dihubungkan menurut garis laki-laki. Lelaki itulah yang membentuk kelompok kekerabatan. Sedangkan perempuan menciptakan hubungan besan (affinal relationship), karena anak perempuan harus kawin dengan laki-laki dari kelompok patrilineal lain.

Seperti yang penulis kemukakan diatas, bagaimana kaitannya dengan ansambel gondang hasapi dan gondang sabangunan, merupakan hal yang sangat penting pada masyarakat Batak Toba, hal ini dapat dilihat darikedudukan seorang pargonsi dalam stratifikasi sosial masyarakat yang tidak permanen dan peranan setiap musisi di ansambel ini pada kegiatan-kegiatan masyarakat dalam konteks religi: adat istiadat dan juga hiburan.

Secara umum sebutan untuk pemain musik Batak Toba yang tergabung dalam permainan ansambel gondang hasapi dan gondang sabangunan disebut dengan pargonsi. Sedangkan sebutan yang bersifat individual untuk setiap pemain musik adalah berdasarkan instrumen yang dikuasainya atau yang dimainkannya, misalnya : sebutan untuk pemain sulim adalah parsulim, sebutan untuk pemain taganing adalah partaganing, sebutan untuk pemain hasapi adalah parhasapi, dan lain sebagainya. Ada juga pemusik yang mampu memainkan alat musik dengan baik. Oleh karena itu sebutan yang diberikan kepada pemusik tersebut adalah berdasarkan permainan musik yang lebih dominan atau lebih menonjol diantara instrumen musik yang dimainkannya.

Selain sebutan yang bersifat kelompok dan individual diatas ada juga sebutan khusus yang diberikan kepada pemain taganing dan pemain sarune yang merupakan penghargaan masyarakat dengan mensejajarkan mereka setara dengan dewa. Gelar yang diberikan untuk pemain taganing (partaganing) adalah 
Batara Guru Htimundul, sedangkan gelar untuk pemain sarune adalah Batara Guru Hiimuntar.

Batara Guru Humundul mempunyai pengertian sebagai dewa pengajar yang duduk di bumi yang mengajari tata cara pelaksanaan adat istiadat pada suatu upacara yang menyertakan gondang dan juga sebagai tempat orang untuk bertanya tentang hal-hal yang berhubungan dengan religi. Batara Guru Humuntar mempunyai pengertian sebagai dewa pengajar yang menyampaikan pesan kepada masyarakat luas melalui suara sarune yang menggelegar.

Menurut Sangti (1973:14), sebutan Batara Guru Humundul dan Batara Guru Humuntar tersebut diberikan adalah karena untuk menjadi seorang partaganing dan parsarune harus memiliki keahlian di bidang permainan musik, pengetahuan tentang ruhutruhut niadat (sendi-sendi adat), pengetahuan tentang keagamaan purba dan juga pengetahuan ilmu-ilmu supranatural. Oleh karena itu tugas partaganing dan parsarune selain sebagai pemusikjuga sebagai paniroi (penasehat) dalam tata cara pelaksanaan upacara. Karena itu mereka berdua selalu mendapat perhatian yang khusus dari pihak suhut (yang melaksanakan upacara), maupun dari pihak lain yang terlibat dalam upacara tersebut. Hal ini disebabkan merekalah yang menyampaikan permohonan dan pujaan kepada partaganing (Yang Maha Esa) dan kepada dewa-dewa bawahannya yang mempunyai hak otonomi melalui suara gondangnya.

Pada masa pra Kristen, apabila diadakan suatu kegiatan adat maupun kegiatan keagamaan yang menyertakan gondang, pihak suhut terlebih dahulu menemui partaganing dan parsanme dengan permohonan yang disertainapuran pangelekan (sirih permohonan) agar mereka (partaganing dan parsanme) berkenan memainkan gondang dalam upacara tersebut. Setelah ada kesepakatan antara suhut dengan partaganing dan parsarune, maka selanjutnya urusan menghubungi pemain ogung, gordang dan hesek langsung ditangani oleh partaganing atau parsanme.

Setelah persiapan upacara dirampungkan, maka pihak suhut (yang mengadakan upacara) harus menjemput pargonsi ke tempat dimana upacara dilaksanakan. Setelah pargonsi sampai ke tempat upacara mereka disambut dengan hormat dan diberikan makan terlebih dahulu. Pada saat upacara akan dimulai maka pihak suhut akan membuat pingganpanungkunan dalam tandok (tempat beras yang terbuat dari anyaman pandan) yang berisi napuran tiar (sirih), boras pir (beras), miak-miak (telor ayam kampung) dan ringgit si tio soara (uang). Hal ini dilakukan sebagai suatu adat istiadat untuk meminta nasehat atau petunjuk dari partaganing dan parsarune dalam pelaksanaan upacara setelah terlebih dahulu menjelaskan latar belakang dan tujuan upacara tersebut.

Pada saat upacara yang berlangsung banyak sebutan yang sering ditujukan kepada pargonsi yang bersifat memuji dan menyanjung antara lain :

1. Parindahan na suk-suk, parlompan na tabo yang secara harfiah berarti nikmat nasi yang banyak, nikmat lauk yang lezat. Hal ini dilakukan karena mengingat bahwa dalam permainan taganing dan sarune harus memiliki stamina fisik yang prima, oleh karena itu pargonsi harus diberikan nasi yang banyak dan lauk yang enak.

2. "Among na malo, dang dope hudok, nunga di boto ho ", yang berarti, "Tuan yang pintar, belum lagi kuucapkan, kau telah mengetahuinya". Ungkapan ini diucapkan karena seorang partaganing dan paxsarune harus bisa membaca permintaan dari paminta gondang (yang meminta gondang), walaupun orang tersebut belum atau tidak menyebutkan reportoar yang akan diminta. 
3. Paralu-alu na tingkos, yang artinya tempat penyampaian pesan yang tepat. Seorang partaganing atau parsarune harus bisa menyesuaikan reportoar yang dimainkan dengan pada siapa pesan atau permohonan itu ditujukan. Misalnya, apabila suatu permintaan gondang ditujukan dalam hubungan manusia dengan manusia maka reportoar gondang yang dimainkan adalah yang berhubungan dengan manusia. Contoh gondang didang-didang, gondang marhaha maranggi (bersaudara), gondang sampur marmeme, dan sebagainya. Apabila pesan ditujukan kepada roh atau dewa-dewa, maka reportoar yang dimainkan adalah gondang debata (dewa), contoh : gondang mulajadi, gondang debata sori, gondang sahala raja, dan lain sebagainya.

4. Partarias na malo, yang artinya pemikir yang bijaksana. Apabila ada sesuatu kesalahan mengenai tata cara di dalam pelaksanaan upacara oleh suhut ataupun diluar suhut, maka pargonsi harus berusaha untuk mengajari ataupun menasehati dengan bahasa yang lembut dan bijaksana.

5. Among pangoloi, among sioloan, yang artinya orang yang mau mengabulkan permintaan tetapi juga yang harus dipatuhi. Setiap permintaan untuk memainkan reportoar gondang oleh paminta gondang (yang meminta gondang), pargonsi selalu mengabulkannya namun apabila pargonsi menasehati atau mengajari tentang sesuatu yang berhubungan dengan upacara tersebut, maka suhut atau orang-orang yang ikut serta dalam kegiatan tersebut harus mematuhinya.

Tempat yang disediakan untuk pargonsi ketika memainkan gondang harus lebih tinggi posisinya dari tempat orang yang manortor (menari). Pargonsi biasanya ditempatkan di para-para (anjungan ruma bolon) atau dibuat tempat khusus yang lebih tinggi dari tempat orang menari (manortor). Hal ini menunjukkan bahwa status pargonsi pada saat itu lebih tinggi dari manusia. Selama upacara sedang berlangsung status pargonsi tetap dianggap sebagai wakil dewa, karena hanya pargonsi melalui suara gondangnya yang dapat menyampaikan permohonan kepada yang disembah. Selain itu, selama upacara sedang berlangsung secara otomatis status pargonsi terlepas dari sistem kekerabatan dalihan na tolu, yakni jabatannya sebagai dongan sabutuha, dongan tubu, boru dan hula-hula. Dengan kata lain, pada saat itu hubungan mereka dengan marga atau dengan status sehari-hari dihilangkan.

Setelah upacara selesai, dibuat lagi acara khusus untuk meminta penjelasan dari pargonsi tentang hal-hal yang sudah dilaksanakan dalam sebuah upacara. Pada pelaksanaan permintaan tersebut, biasanya disertai dengan pinggan panungkunan (sejenis tempat beras yang dianyam dari daun pandan) yang berisi boras pir (beras), napuran (sirih), miak-miak (telur ayam kampung) dan ringgit si tio soara (uang). Pada saat inilah pihak pargonsi akan menjelaskan apakah pelaksanaan upacara tersebut membawa rezeki atau tidak. Dengan kata lain apakah permohonan dari pihak suhut dikabulkan oleh dewa atau tidak. Pargonsi akan menjelaskan hal tersebut melalui tanda-tanda yang dilihat atau dirasakan sejak upacara dimulai hingga selesai. Dalam hal ini, pargonsi akan menganjurkan apa yang harus dilakukan lagi oleh suhut untuk kelanjutan dari apa yang sudah dilaksanakan. Setelah semuanya selesai, maka diberikanlah upah pargonsi berupa beras, daging dan uang kemudian diantar pulang.

Demikianlah kedudukan seorang pargonsi dalam stratifikasi sosial masyarakat yang tidak permanen. Di satu sisi dianggap sebagai wakil dewa, yaitu ketika memainkan ansambel gondang pada saat upacara, di sisi lain sebagai masyarakat biasa yang terikat dengan sistem kemasyarakatan dan kekerabatan yang terdapat dalam dalihan na 
tolu tetika tidak berperan sebagai pargonsi. Status mereka adalah sama dengan individu lainnya berdasarkan pekerjaan sehari-hari, misalnya sebagai petani, nelayan, pedagang dan sebagainya.

Akan tetapi sejalan dengan perkembangan zaman dan kebudayaan Batak Toba, sekitar tahun 1968 masyarakat sudah sering menggunakan musik tiup dalam kegiatan yang berhubungan dengan adat maupun hiburan. Panggilan terhadap pemain musik tiup sering disebut dengan pargonsi. Umpasa umpasa yang dulunya ditujukan kepada pemusik tradisional Batak (pemain gondang) pada saat itu sudah ditujukan juga kepada pemusik tiup, misalnya "parindahan na suksuk parlompan na tabo"," among na malo" dan sebagainya. Namun walaupun sebutan pargonsi tersebut ditujukan juga kepada pemusik tiup, akan tetapi gelar Batara Guru Humunndul dan Batara Guru Humuntar tidak pemah ditujukan untuk pemain drum atau pemain saxophone. Oleh karena itu dapat diambil kesimpulan bahwa stratifikasi sosial yang mensejajarkan pemusik dengan dewa hanya didapati pada pemusik gondang sabangunan dan gondang hasapi. Stratifikasi pargonsi khususnya instrumen taganing(membranophone) yang disebut partaganing mendapat posisi khusus karena dianggap sebagai seorang yang memiliki kemampuan sebagai penghubung antara manusia dengan sang pencipta.

\subsection{Dasar Klasifikasi Instrumen}

Klasifikasi instrumen musik yang modern dirintis oleh Victor Mahillon (18411924) yang bekerja pada Instrumental Museum of The Conservatiore Royal deMusique, Brusels, Belgia, sejak didirikan pada tahun 1877. Koleksi dasar museum ini pada umumnya terdiri dari instrumen musik yang dipakai dan terdapat pada orkes simfoni Eropa. Kemudian berkembang dengan memasukkan instrumen-instrumen musik dari sebagian besar kawasan dunia. Tujuan dari sistem Mahillon pada masa itu adalah untuk menginventarisir atau mengkalogkan keseluruhan koleksi instrumen musik yang berangsur-angsur semakin banyak hingga berkisar tiga ribu jenis.

Dasar klasifikasi instrumen musik yang dilakukan oleh Victor Mahillon berprinsip pada pembagian instrumen musik yang telah ada pada tulisan Hindu Kuno yang mana di dalamnya terdapat empat kelas dasar, yaitu: (1) instrumen musik pukul, (2) instrumen musik yang mempunyai membran (berhubungan dengan cara merenggangkan kulit dimulut gendang), (3) instrumen musik berongga atau instrumen musik tiup, dan (4) instrumen musik berdawai (alat musik yang memiliki senar).

Mahillon membagi alat musik perkusi (pukul) ke dalam dua kelompok sub divisi yaitu, autophones (autofon) yang terdiri dari alat musik yang badannya sendiri menghasilkan suara apabila dibunyikan dengan alat penggetar, dan membranophones (membranofon) yaitu berdasarkan hasil suara yang disebabkan oleh getar membrannya, seperti kulit gendang.

Prinsip-prinsip divisi dalam klasifikasi instrumen, masih berpedoman pada sistem Mahillon. Kemudian sistem- sistem tersebut disusun dalam hirarki-hirarki dengan sejumlah level yang terdiri dari : kelas, cabang, seksi, dan sub seksi. Dimana media yang memproduksi bunyi merupakan dasar pada devisi dan mewakili sebuah prinsip dari divisi suatu instrumen.

Mahillon-Sachs-VonHornbostel

membuat pengelompokan atau klasifikasi instrumen berdasarkan bahan yang memproduksi suara, dan terbatas pada aspek akustik. Klasifikasi tersebut terbagi dalam 5 kelompok yaitu :

1. Idiofon (bahan alat musik itu sendiri yang menghasilkan bunyi).

2. Aerofon (udara atau satuan udara yang berada dalam alat musik itu sebagai sumber bunyi). 
3. Membranofon (kulit atau selaput tripis yang direnggangkan sebagai sumber bunyi).

4. Kordofon (senar/dawai yang ditegangkan sebagai sumber bunyi).

\subsection{Klasifikasi Instrumen Musik Pada Ansambel Musik Tradisional Batak Toba}

Jenis Alat Musik Tradisional Batak Toba

Pada etnik Batak Toba dapat dibuat pengklasifikasian instrumen dari jenis alat-alat musik yang dimainkan baik dalam bentuk ansambel atau sebagai alat musik individual yang dimainkan secara solo. Ragam alat musik tersebut adalah sebagai berikut:

1. Sarune Bolon yaitu, alat musik pembawa melodi yang memiliki reed ganda (double reed). Dimainkan dengan cara mangombus marsiulakhosa (circular breathing). Klasifikasi instrumen ini termasuk ke dalam kelompok aerophone.

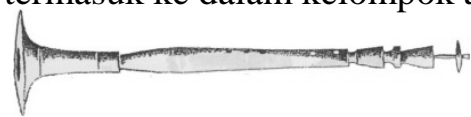

Gambar 1. Sarune Bolon

2. Sarune Etek yaitu, alat musik pembawa melodi yang memiliki reed tunggal (single reed).Memiliki lima lobang nada (empat disebelah atas, satu disebelah bawah) dimainkan dengan cara mangombus marsiulak hosa (meniup dengan cara terus menerus).Klasifikasi instrumen ini termasuk ke dalam kelompok aerophone.

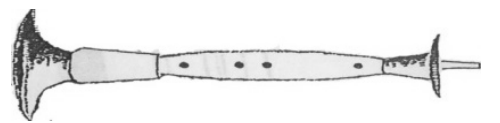

Gambar 2. Sarune Etek

3. Garantung adalah instrumen pembawa melodi yang terbuat dan kayu dan memiliki lima bilah nada. Selain berperan sebagai pembawa melodi, juga berperan sebagai pembawa ritem variabel pada lagu-lagu tertentu. Dimainkan dengan cara memukul dengan menggunakan stick. Klasifikasi instrumen ini termasuk kedalam kelompok xylophone.

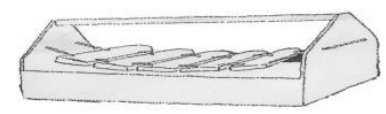

Gambar 3. Garantung

4. (Purba 2007:8) Taganing (single-headed braced drum) yang dalam permainannya keduanya memainkan melodi yang sama, bisa secara heteroponi dan bisa pula secara polyphony tanpa adanya ikatan tonal yang sama. Taganing serangkaian gendang yang terdiri dari 5 buah. Disusun dalam satu standar berturut-turut dari bentuk yang lebih besar hingga yang terkecil berfungsi sebagai pembawa melodi dan ritme variabel pada lagu-lagu tertentu. Dimainkan dengan cara memukul kulitnya dengan palu-palu (stick). Klasifikasi instrumen ini termasuk kedalam kelompok membranophone.

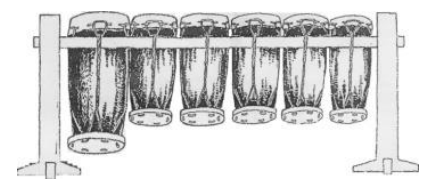

Gambar 4. Taganing dan Gordang

5. Gordang (single headed drum), yaitu satu buah gendang yang lebih besar dari taganing yang berperan sebagai pembawa ritem konstan maupun ritem variabel. Instrumen ini sering disebut sebagai bass dari ansambel gondang sabangunan. Perhatikan gambar 4, gordang terletak pada posisi kiri, dengan bentuk yang lebih besar dari taganing. Klasifikasi instrumen ini termasuk kedalam kelompok membranophone.

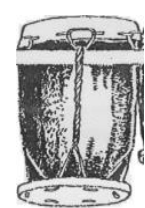

Gambar 5. Gordang

6. Odap (double headed drum), yaitu gendang dua sisi yang berperan sebagai pembawa ritem variabel. Instrumen ini 
dimainkan untuk lagu-lagu tertentu dalam gondang sabangunan dan sering digunakan ketika pawai. Klasifikasi instrumen ini termasuk kedalam kelompok membranophone.

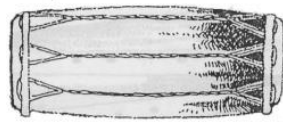

Gambar 6. Odap

7. Hasapi ende (plucked lute dua senar) adalah instrumen pembawa melodi dan merupakan instrumen yang dianggap paling utama dalam ansambel gondang hasapi. Tune atau stem dari kedua senamya adalah dengan interval ters mayor yang dimainkan dengan cara mamiltik (memetik).Klasifikasi instrumen ini termasuk kedalam kelompok chordophone

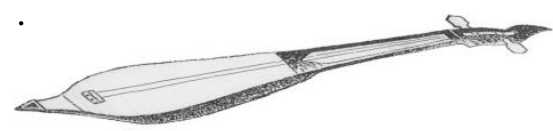

Gambar 7. Hasapi Ende

8. Hasapi doal, alat musik ini sama dengan hasapi ende namun dalampermainannya hasapidoal berperan sebagai pembawa ritme konstan. Ukuran instrumen hasapai doal sedikit lebih besar dari hasapi ende. Klasifikasi instrumen ini termasuk kedalam kelompok chordophone

9. Ogung (gong), yaitu empat buah gong yang diberi nama oloan, ihutan, doal dan panggora. Setiap ogung mempunyai ritem yang sudah konstan. Instrumen ini berperan sebagai pembawa ritem konstan atau pembawa irama dalam gondang sabangunan. Klasifikasi instrumen ini termasuk kedalam kelompok idiophone.

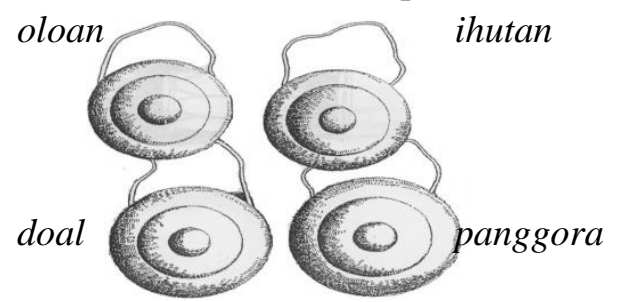

Gambar 8. Ogung (gong)
10. Sulim (transverse flute), yaitu alat musik yang terbuat dari bambu, memiliki enam lobang nada dan satu lobang tiup. Dimainkan dengan cara meniup dari samping (side blown flute) yang dilakukan dengan meletakkan bibir secara horizontal pada pinggir lobang tiup. Instrumen ini biasanya memainkan lagu-lagu yang bersifat melankolis ataupun lagu-lagu sedih. Klasifikasi instrumen ini termasuk ke dalam kelompok aerophone.

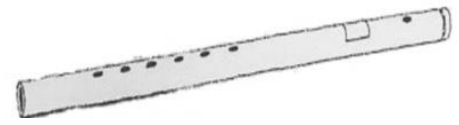

Gambar 9. Sulim

11. Talatoit (transverse flute), yaitu alat musik yang terbuat dari bambu, sering juga disebut dengan salohat atau tulila. Dimainkan dengan cara meniup dari samping. Mempunyai empat lubang penjarian yakni dua di sisi kiri dan dua di sisi kanan, sedangkan lubang tiup berada di tengah. Instrumen ini biasanya memainkan lagu-lagu yang bersifat melodis dan juga bersifat ritmik. Klasifikasi instrumen ini termasuk dalam kelompok aerophone.

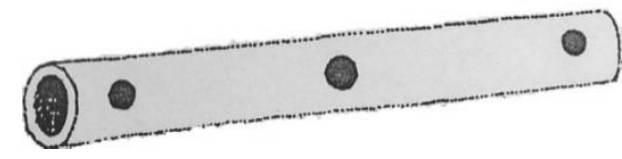

Gambar 10. Talatoit

12. Sordam (long flute) yang terbuat dari bambu. Dimainkan dengan cara meniup dari ujungnya (up blown flute) dengan meletakkan bibir pada ujung bambu secara diagonal. Memiliki enam lubang nada, yakni lima di bagian atas dan satu di bagian bawah, sedangkan lubang tiupnya merupakan ujung dari bambu tersebut. Klasifikasi instrumen ini termasuk dalam kelompok aerophone.

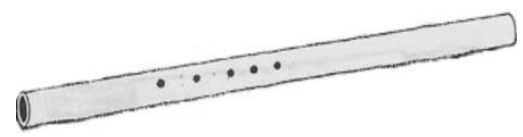




\section{Gambar 11. Sordam}

13. Tanggetang, yaitu alat musik yang senamya terbuat dari rotan dan peti kayu sebagai resonator. Permainan instrumen ini bersifat ritmik atau mirip dengan gaya permainan gong maupun gaya permainan mengnmng. Klasifikasi instrumen ini termasuk ke dalam kelompok kordophone.

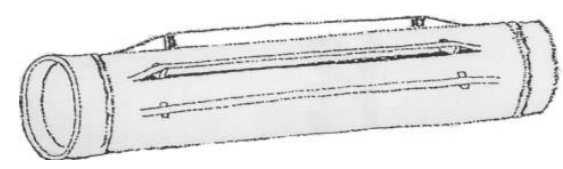

Gambar 12. Mengmung

14. Saga-saga (few's harp) yang terbuat dari bambu dimainkan dengan cara menggetarkan lidah dari instrumen tersebut dan rongga mulut berperan sebagai resonator. Klasifikasi instrumen ini termasuk kedalam kelompok idiophone.

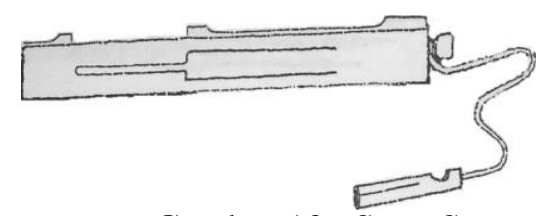

Gambar 13. Saga-Saga

Etnik Batak Toba mengakui bahwa gondang adalah ciptaan dari Mulajadi $\mathrm{Na}$ Bolon dan merupakan milik dewa-dewa. Manusia hanya diberikan hak untuk menyimpan dan menggunakannya. Alasan yang membuktikan bahwa gondang adalah ciptaan dari Mulajadi Na Bolon dapat dilihat dari suatu upacara, dimana gondang (bunyi gondang) dapat menyampaikan permohonan manusia kepada dewa-dewa. Selain itu konsep religi yang menganggap bahwa gondang merupakan milik dewa-dewa dapat dilihat dalam konsep sipitu gondang (tujuh repertoar gondang). Dalam setiap upacara yang menyertakan gondang baik dalam konteks adat maupun religi, penyajian sipitu gondang selalu dilakukan pada bagian pembuka dan pada bagian penutup.

\subsection{Ansambel Batak Toba}

Dalam etnik Batak Toba terdapat dua jenis ensambel musik yaitu, ensambel Gondang Sabangunan dan Gondang Hasapi. Secara umum, fungsi dan penggunaan musik dalam bentuk ansambel mempunyai konsep dan tujuan yang sama. Gondang hasapi dan gondang sabangunan sama-sama digunakan untuk upacara adat maupun untuk upacara yang bersifat religius. Perbedaan penggunaan kedua ansambel tersebut hanya terletak pada sifat dari upacara tersebut, yaitu untuk upacara yang melibatkan masyarakat luas biasanya menggunakan ansambel gondang sabangunan. Selain dalam bentuk formasi ensambel, pada masyarakat ini terdapat permainan musik yang bersifat individual, serta berbagai jenis musik vokal.

\section{Ensambel Gondang Sabangunan}

Ansambel gondang sabangunan mempunyai beberapa istilah yang sering digunakan oleh masyarakat Batak Toba, yakni ogung sabangunan dan gondang bolon. Instrumen yang termasuk dalam kelompok gondang sabangunan antara lain : taganing, gordang, odap, ogung, sarune, ogung ihutan, doal, panggora, hesek.

Pada masa Pra Kristen, gondang sabangunan digunakan untuk berbagai upacara yang berhubungan dengan upacara adat maupun upacara religius. Pada masyarakat ini istilah gondang juga diartikan sebagai media yang menghubungkan manusia dengan penciptanya atau yang disembahnya dalam hubungan vertikal juga sebagai media yang menghubungkan manusia dengan sesamanya dalam hubungan horizontal (Purba, 2003)

Dalam permainan gondang sabangunan instrumen odap belakangan sudah jarang digunakan karena permainan dari odap tersebut dapat digantikan dengan menggunakan taganing dan mempunyai suara yang sama. Tangga nada yang ada dalam instrumen pembawa melodi yakni taganing dan sarune bolon mempunyai tangga nada 
yang pentatonis. Namun dalam hal ini istilah pentatonis yang terdapat dalam gondang sabangunan bukan seperti konsep pentatonis yang ada dalam musik barat melainkan hanya suatu sebutan terhadap tangga nada yang mempunyai lima nada dalam konsep gondang sabangunan.

Mengacu pada dasar klasifikasi instrumen maka pada etnik Batak Toba dapat dibuat pengklasifikasian instrumen dari jenis alat-alat musik yang dimainkan dalam bentuk ansambelgondang sabangunan.Ragam Alat Musik Dalam Ensambel Gondang Sabangunan dan pengklasifikasiannya

1. Taganing, klasifikasi instrumen ini termasuk kedalam kelompok membranophone.

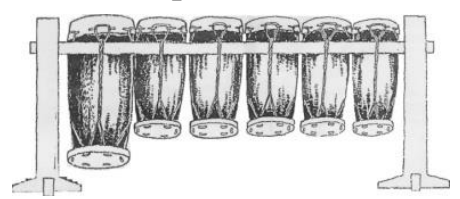

2. Gordang, dari posisi gambar diatas gordang terletak pada posisi kiri, dengan bentuk yang lebih besar dari taganing. Klasifikasi instrumen ini termasuk kedalam kelompok membranophone.

3. Odap, klasifikasi instrumen ini termasuk kedalam kelompok membranophone.

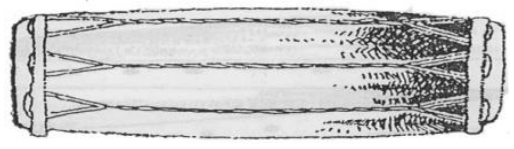

4. Ogung (gong), yaitu empat buah gong yang diberi nama oloan, ihutan, doal dan panggora.

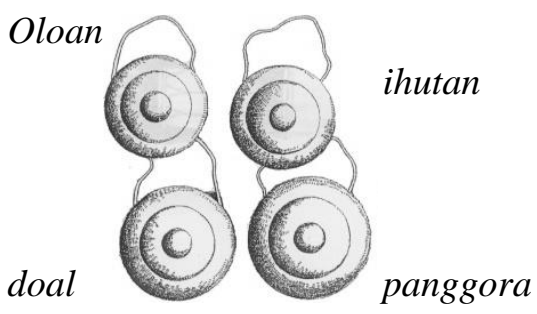

5. Sarune Etek,klasifikasi instrumen ini termasuk dalam kelompok aerophone.

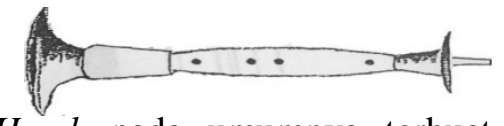

6. Hesek pada umumnya terbuat dari dua bilah besih yang dipukulkan, apabila tidak ada besi maka digantikan dengan menggunakan botol, hesek memainkan ritem yang konstan dalam seluruh repertoar gondang sabangunan, klasifikasi instrumen ini termasuk dalam kelompok idiophone

Pada dasamya permainan instrumen taganing dan sarune terjalin dalam hubungan melodi yang heteroponis dimana kedua instrumen tersebut membawakan melodi yang sama dalam beberapa reportoar, namun tangganada maupun tonalitasnya berbeda. Oleh karena itu istilah heteroponis untuk sarune dan taganing ini terjalin dalam heteroponis polytonal.

\section{Ensambel Gondang Hasapi}

Mengacu pada dasar klasifikasi instrumen maka pada etnik Batak Toba dapat dibuat pengklasifikasian instrumen dari jenis alat-alat musik yang dimainkan dalam bentuk ansambelgondang hasapi.Ansambel gondang hasapi memiliki beberapa alat musik yang terdiri dari :

1. hasapi ende, Klasifikasi instrumen ini termasuk kedalam kelompok chordophone.

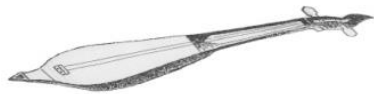

2. Hasapi doal, instrumen ini sama dengan hasapi ende namun dalam permainannya hasapidoal berperan sebagai pembawa ritem konstan. Ukuran instrumen hasapai doal lebih besar sedikit dari hasapi ende.

3. Sarune etek,klasifikasi instrumen ini termasuk dalam kelompok aerophone

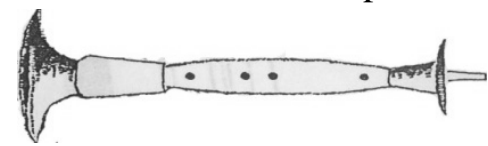

4. Sulim, klasifikasi instrumen ini termasuk dalam kelompok aerophone

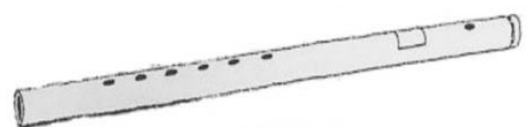


5. Garantung,klasifikasi instrumen ini termasuk kedalam kelompok xylophone.

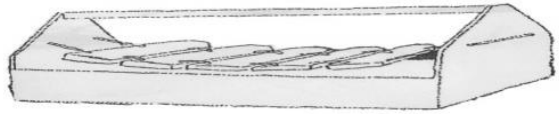

6. Hesek pada umumnya terbuat dari dua bilah besih yang dipukulkan, apabila tidak ada besi maka digantikan dengan menggunakan botol, hesek memainkan ritem yang konstan dalam seluruh repertoar gondang sabangunan, klasifikasi instrumen ini termasuk dalam kelompok idiophone

Prinsip klasifikasi berdasarkan uraian yang dikemukakan oleh Mahillon-SachsVonHornbostel dalam kaitannya dengan pengelompokan alat musik yang dilakukan secara lokal pada alat-alat musik tradisional Batak Toba, pada prinsipnya mengacu pada teori klasifikasioleh Mahillon-SachsVonHornbostelnamun di sisi lain secara spesifik pengelompokan yang dilakukan secara local, berdasar pada fungsi alat musik dalam sebuah ansambel baik pada gondang sabangunan maupun gondang hasapi.

\section{SIMPULAN}

Hasil kajian ini menunjukkan bahwa klasifikasi instrumen Batak Toba di klasifikasikan untuk ansambel gondang sabangunan, taganing (membranophone), gordang (membranophone), odap (membranophone), ogung oloan (idiophone), sarune (aerophone), ogung ihutan (idiophone), doal (idiophone), panggora (idiophone), hesek (idiophone) untuk ansambel gondang hasapi, hasapi ende (chordophone), hasapi doal (chordophone), sarune etek (aerophone), sulim (aerophone), garantung (idiophone, hesek (idiophone).

Stratifikasi pargonsi khususnya instrumen taganing(membranophone) yang disebut partaganing mendapat posisi khusus karena dianggap sebagai seorang yang memiliki kemampuan sebagai penghubung antara manusia dengan sang
pencipta.Kedudukan seorang pargonsi dalam stratifikasi sosial masyarakat yang tidak permanen. Di satu sisi dianggap sebagai wakil dewa, yaitu ketika memainkan ansambel gondang pada saat upacara, di sisi lain sebagai masyarakat biasa yang terikat dengan sistem kemasyarakatan dan kekerabatan yang terdapat dalam dalihan na tolu tetika tidak berperan sebagai pargonsi. Status mereka adalah sama dengan individu lainnya berdasarkan pekerjaan sehari-hari, misalnya sebagai petani, nelayan, pedagang dan sebagainya.

Prinsip klasifikasi berdasarkan uraian yang dikemukakan oleh Mahillon-SachsVonHornbostel dalam kaitannya dengan pengelompokan alat musik yang dilakukan secara lokal pada alat-alat musik tradisional Batak Toba, pada prinsipnya mengacu pada teori klasifikasi oleh Mahillon-SachsVonHornbostelnamun di sisi lain secara spesifik pengelompokan yang dilakukan secara local, berdasar pada fungsi alat musik dalam sebuah ansambel baik pada gondang sabangunan maupun gondang hasapi.

\section{DAFTAR PUSTAKA}

[1] Ben, R.(2000).Musik Tradisional. Diktat Jurusan Bahasa Dan Sastra Universitas Negeri Medan.

[2] Blacking, J.(1995). "Music, Culture and Experience".London:University of Chicago Press.

[3] Coplan, D. B. (1993). "Ethnomusicology and the Meaning of Tradition" dalam Ethnomusicology and Modern Music Hystory. Stephen Blum, Philipp V. Bohlman dan Daniel M. Neuman (Ed). Urbana and Chicago: University of Illionis Press.

[4] Djohan. (2003). "Psikologi Musik". Yogyakarta: Buku Baik. 
[5] Mahilon, V. C.(1974). "Elements d'acoustigue musicale \& instrumental". Brussels: C. Mahillon

[6] Moleong, L. J. (2001). Metode Penelitian Kualitatif. Bandung: PT. Remaja Rosdakarya.

[7] Pasaribu. B. M. (1986). "Taganing Batak -Toba: Suatau Kajian Konteks Sabangunan". Skripsi Sarjana USU Fakultas Sastra Jurusna Etnomusikologi, Medan.

[8] Purba, M.(2007)."Musik Tradisional Masyarakat Sumatera Utara:Harapan, Peluang Dan Tantangan", Pidato Pengukuhan Jabatan Guru Besar Tetap Dalam Bidang Ilmu Etnomusikologi Pada Fakultas Sastra Universitas Sumatera Utara Medan.

[9] Takari, M. dkk, (2008). "Masyarakat Kesenian di Indonesia" Studi Kultura, Fakultas Sastra Universitas Sumatera Utara Medan.

[10] http://wikipedia/hornbostel-sach.com 